\title{
First evaluation of foraminiferal metabarcoding for monitoring environmental impact from an offshore oil drilling site
}

\author{
Olivier Laroche ${ }^{1,2^{*}}$, Susanna A Wood ${ }^{1,3}$, Louis A Tremblay ${ }^{1,2}$, Joanne I Ellis ${ }^{4}$, Franck \\ Lejzerowicz ${ }^{5}$, Jan Pawlowski ${ }^{5}$, Gavin Lear ${ }^{2}$, Javier Atalah ${ }^{1}$, Xavier Pochon ${ }^{1,6}$ \\ ${ }^{1}$ Environmental Technologies, Coastal and Freshwater Group, Cawthron Institute, Private Bag 2, Nelson \\ 7042, New Zealand; \\ ${ }^{2}$ School of Biological Sciences, University of Auckland, Private Bag 349, Warkworth 0941, New Zealand; \\ ${ }^{3}$ Environmental Research Institute, University of Waikato, Private Bag 3105, Hamilton 3240, New \\ Zealand; \\ ${ }^{4}$ Red Sea Research Centre, King Abdullah University of Science and Technology, Thuwal, Saudi Arabia; \\ ${ }^{5}$ Department of Genetics and Evolution, University of Geneva, Switzerland \\ ${ }^{6}$ Institute of Marine Science, University of Auckland, Private Bag 349, Warkworth 0941, New Zealand;
}

Keywords: Benthic ecology, biomonitoring, foraminifera, high-throughput sequencing, metabarcoding, oil and gas drilling operations.

* Corresponding author 


\begin{abstract}
At present, environmental impacts from offshore oil and gas activities are partly determined by measuring changes in macrofauna diversity. Morphological identification of macrofauna is timeconsuming, expensive and dependent on taxonomic expertise. In this study, we evaluated the applicability of using foraminiferal-specific metabarcoding for monitoring. Sediment samples were collected along distance gradients from two oil platforms off Taranaki (New Zealand) and their physico-chemical properties, foraminiferal environmental DNA/RNA, and macrofaunal composition analysed. Macrofaunal and foraminiferal assemblages showed similar shifts along impact gradients, but responded differently to types of environmental perturbations. Macrofauna were affected by hypoxia, whereas sediment grain size appeared to drive shifts in foraminifera. We identified eight foraminiferal molecular operational taxonomic units that have potential to be used as bioindicator taxa. Our results show that metabarcoding represent an effective tool to assess foraminiferal communities near offshore oil and gas platforms, and that it can be used to complement current monitoring techniques.
\end{abstract}




\section{Introduction}

The demand for oil is expected to increase by 18.7 million barrels per day $(\mathrm{mb} / \mathrm{d})$ over the next 25 years, reaching $111 \mathrm{mb} / \mathrm{d}$ by 2040 (Organisation of the Petroleum Exporting Countries [OPEC], 2014). Moreover, the gas sector is expected to become the predominant source of energy beyond 2040 (International Energy Agency [IEA], 2012), and offshore and deep-water production will continue to rise as onshore reserves diminish (LUKOIL, 2013). As offshore oil and gas production rises, the need for effective benthic monitoring that can provide early detection of environmental changes will be increasingly important. Currently, benthic monitoring of these environments involve the sorting, identification and enumeration of macrofaunal assemblages using microscopy. This approach is laborious, costly, and relies on expert taxonomic knowledge (Borja et al., 2009; Fernandes et al., 2001).

Recent breakthroughs in high-throughput sequencing (HTS) technologies allow for species diversity to be estimated rapidly from small amounts (2-10 g) of sediment using a technique known as environmental DNA (eDNA) metabarcoding (Baird and Hajibabaei, 2012; Bourlat et al., 2013; Dowle et al., 2015a; Taberlet et al., 2012). Metabarcoding enables the identification of organisms without taxonomic expertise by matching short gene fragments (from HTS data) to a reference sequence library. Standardized protocols can be developed and the results are defendable and auditable (Ji et al., 2013; Valentini et al., 2009). These qualities make metabarcoding a cost-effective, reliable and rapid option to meet the increasing need for largescale environmental impact assessments. Although the lack of reference sequences in barcoding libraries still represent an impediment to routine implementation of HTS methods, the continued improvement and accessibility of genomic tools is rapidly increasing the number of DNA barcodes available, which will reduce taxonomic assignment issues (Cristescu, 2014). 
Metabarcoding studies of macrofauna have generally been limited to free DNA (extra and intracellular DNA from dead cell [e.g. feces, urine, moult, mucus; Taberlet et al., 2012]). Conversely, studies on meio and microfauna can be either based on external and internal DNA, and RNA (e.g. Dowle et al., 2015b; Lejzerowicz et al. 2013, 2014). Due to the persistence of DNA in the environment, eDNA samples may reflect living and dead assemblages, creating biases when performing ecological surveys (Lillis et al., 2009; Mengoni et al., 2005). RNA degrades rapidly and is therefore more likely to provide an accurate assessment of the living organisms in a sample (Lillis et al., 2009; Pawlowski et al., 2014a; Pochon et al., 2015).

Foraminifera are an abundant group of protists (up to thousands of individuals per $10 \mathrm{~cm}^{3}$ ) that form an essential component of marine sediment communities (Murray, 2006; Sen Gupta, 2002). Foraminifera are responsive to local conditions and have shorter life-cycles than macrofauna, making them good indicators of current and recent environmental perturbations, including organic enrichment, oil discharges, metal contamination and physical disturbances (Alve, 1999; Bergin et al., 2006; Casey et al., 1980; Ernst et al., 2006; Mojtahid et al., 2008). They have also been shown to display slightly higher sensitivity to oil-based drilling mud than macrofauna (Denoyelle et al. 2010). Additionally, mineral-walled forms of foraminifera leave a microfossil record that can provide data for pre-pollution assessment in cases where no baseline studies are available (Ernst et al., 2006; Hayward et al., 2004; Hess et al., 2013; Schafer, 2000).

An extensive database of foraminiferal DNA sequences has been accumulated over two decades of research (Pawlowski et al. 2014a), providing a solid taxonomic framework for comprehensive metabarcoding. Diversity surveys using metabarcoding on environmental DNA (eDNA) have dramatically changed traditional taxonomic notions of foraminifera. For example, eDNA analysis has revealed an unexpectedly high diversity of monothalamous (single- 
chambered) foraminifera in benthic ecosystems (Lecroq et al., 2011; Pawlowski et al., 2011). Foraminiferal metabarcoding has recently been applied to assess the impact of salmon farming activities in sheltered fjords, where communities and species-specific responses strongly correlate to organic enrichment, especially when using eRNA (Pawlowski et al., 2014b; Pochon et al., 2015). This provided the impetus to explore the use of this molecular monitoring tool to measure the impact of a wider range of perturbations in the marine environment.

In this study, we investigated, for the first time, the use of foraminiferal metabarcoding to assess the impact of exploratory offshore drilling activities. The overarching aim was to determine whether foraminiferal metabarcoding can be used to detect shifts in overall communities or identify key bioindicator taxa, which align with variation in the environmental gradients associated with this type of industrial marine activity.

Biological samples (foraminiferal and macrofaunal assemblages) and physico-chemical data were collected along transects radiating to the north and south of two oil wellheads (WHs) drilled off the Taranaki region, New Zealand. Both sites were characterized by coarser sediments, hypoxic conditions, low organic content, and higher concentrations of barium and arsenic at their WHs (Skilton et al., 2015). We hypothesized that: (1) environmental foraminiferal DNA and RNA (eDNA/eRNA) assemblages would show stronger responses than macrofauna to shifts in environmental conditions caused by oil and gas operations, and (2) key foraminiferal taxa could be identified that were indicative of these environmental changes. 


\section{Material and Methods}

\subsection{Field sampling}

The study area was located $35 \mathrm{~km}$ off the west coast of New Zealand's North Island, in the South Taranaki Bight (Figure 1A). In this region, the seabed is mostly uniform, consisting of soft sediment and with water depth ranging between 120 to $130 \mathrm{~m}$. Between May and June 2014, well Oi-1 (39 21'019"S, 173²0'027"E) was drilled and $319 \mathrm{~m}^{3}$ of water-based drilling mud and cuttings material were discharged at sea from the platform (Skilton et al., 2015) using the process described in Govier and Calder (2013). Due to drilling difficulties, another well, Oi-2 $\left(39^{\circ} 20^{\prime} 955^{\prime \prime} \mathrm{S}, 173^{\circ} 20^{\prime} 087^{\prime \prime} \mathrm{E}\right)$, was spudded 150 m northeast of the former between June and July 2014, with the additional release of $243 \mathrm{~m}^{3}$ of drilling material (Skilton et al., 2015).

The methodology used for sampling was based on the Offshore Taranaki Environmental Monitoring Protocol (OTEMP; Johnston et al. 2014a). It consists of a distance-graded sample station allocation. In this specific area, the north-south axis constitutes the main trajectory along which deposition of drilling mud and cuttings occurs (MetOcean Solutions Limited [MSL], 2013). Sampling stations were overlaid along this axis with the drilling rig located at the center (Figure 1B). Twelve stations were sampled at Oi-2. One of these stations was directly adjacent to the drilling site. These samples provided a unique opportunity to study potential impact at sites close to WHs. Most monitoring programmes are unable to obtain samples within a $250 \mathrm{~m}$ radius from WHs. In this study, it was possible to obtain these samples because the sites were used for exploratory purposes only, and all activity ceased shortly after drilling. The remaining stations were located both northward and southward from the WH at approximately 100, 250, 500, 1000 and 2000, and one station situated at $4000 \mathrm{~m}$ northward from the WH. Two other stations were 
centered around Oi-1, one at the WH and one $100 \mathrm{~m}$ south. Two control sites were located $15 \mathrm{~km}$ south-east and $50 \mathrm{~km}$ south-west of the WH respectively (Figure 1).

Using a modified stainless steel double van-Veen grab (Johnston et al., 2014), a total of 51 sediment samples were collected between August and October 2014, corresponding to 17 stations in triplicate (i.e., the grab was sent three times to the seafloor at each station; Table S1). To avoid creating a bow wake effect and disturbing the top sediment layer, the grab sampler was deployed and retrieved at a constant rate of $0.3 \mathrm{~m} / \mathrm{s}$. Upon retrieving the grab, the surface was inspected and samples only taken when the surface sediment was undistributed. The grab is divided into two compartments. The full contents of the first compartment was sieved through a $500 \mu \mathrm{m}$ mesh and preserved in $70 \%$ ethanol for analysis of macrofaunal communities. Subsamples (2 g) of undisturbed surface sediment (approximately $1 \mathrm{~cm} \mathrm{depth}$ ) were collected from the second compartment for foraminiferal eDNA/eRNA metabarcoding. These samples were placed in Life Guard ${ }^{\mathrm{TM}}$ Soil Preservation Solution $(5 \mathrm{ml}$; MoBio, USA) using disposable gloves and spatulas, stored on ice during transportation to the laboratory and kept frozen $\left(-20{ }^{\circ} \mathrm{C}\right)$ until further processing. The remainder of the second compartment was sampled for the analysis of sediment texture, organic content or ash-free dry weight (AFDW), trace metals (arsenic [As], barium [Ba], cadmium [Cd], chromium [Cr], copper [Cu], lead [Pb], nickel [Ni], zinc [Zn], mercury $(\mathrm{Hg})$ ), screen metals (manganese $[\mathrm{Mn}]$, iron $[\mathrm{Fe}]$ ), polycyclic aromatic hydrocarbons (PAHs) and total petroleum hydrocarbon (TPHs).

\subsection{Laboratory analysis}

\subsubsection{Samples processing}

Grain size analysis was performed by Resource and Environmental Management Ltd (REM) based in Nelson, NZ, following the protocol described in Skilton et al. (2015). Sediment 
classes were determined using the Wentworth grain size classification (Wentworth, 1922). All chemical analyses of sediment samples were performed by Hill Laboratories Ltd (Blenheim, New Zealand), following analytical methods described in Skilton et al. (2015). A summary of the analytical methods and their detection limit used for the physico-chemical characterisation of sediments is provided in supplementary information (Table S2).

Taxonomists from REM sorted, identified and enumerated macrofaunal organisms to the lowest possible taxonomic level (Macrofauna Count Data; MCD). Information on taxa detected and their abundance per sample can be found in supplementary information (Table S3).

Total DNA/RNA co-extraction from each sample was performed using the PowerSoil ${ }^{\mathrm{TM}}$ Total RNA Isolation Kit and the DNA Elution Accessory Kit (MoBio, USA) following the manufacturer instructions. The quality of DNA and RNA was assessed on 1.5\% agarose gels and using a Nanophotometer (Implen, Munich, Germany). To ensure complete elimination of trace DNA in isolated RNA, samples were submitted to two sequential DNase treatments as described in (Langlet et al., 2013). Treatment efficiency was then verified after PCR amplification (50 cycles) using the DNA-specific foraminiferal forward primer s14F3 (5' ACGCAMGTGTGAAACTTG - $\left.3^{\prime}\right)$ and the reverse primer s15.3 (5' CCTATCACATAATCATGAAAG - 3'), following Pawlowski et al. (2014b). Treated RNA was reverse transcribed using the SuperScript ${ }^{\circledR}$ III reverse transcriptase (Life Technologies). All extract products were stored frozen $\left(-20{ }^{\circ} \mathrm{C}\right.$ for DNA/cDNA; $-80{ }^{\circ} \mathrm{C}$ for RNA) until further analysis.

2.2.2. PCR amplification, high-throughput sequencing, and bioinformatic analysis

Polymerase chain reactions, HTS and foraminiferal metabarcoding data analysis were performed as described in Pochon et al. (2015). Briefly, the foraminiferal-specific 37f 
hypervariable region of the nuclear Small Sub-Unit (SSU) rRNA gene was PCR amplified with tag-modified primers s14F1 (5' - AAGGGCACCACAAGAACGC - 3') and s15 (5' CCACCTATCACAYAATCATG - 3') from each eDNA and eRNA extract (Tables S4 and S5). These primers are specific to Foraminifera (Pawlowski and Lecroq, 2010) and have repeatedly been used to generate metabarcoding data (e.g. Lecroq et al., 2011; Lejzerowicz et al., 2014; Pochon et al., 2015). No other taxon than Foraminifera has ever been detected in such data as the targeted region of the SSU rRNA gene exhibits a conserved part only occurring in foraminiferal sequences (Pawlowski et al., 2014b). From the 51 samples processed, a total of 37 PCRs were positive for the eDNA samples as well as 37 for the eRNA samples, generating a total of 74 amplicons (Table S1). The two groups of 37 PCR products were treated separately for equimolar multiplexing, library preparations using the TruSeq Nano PCR-free Library Preparation kit (Illumina), and sequencing on standard Illumina ${ }^{\mathrm{TM}}$ MiSeq flow cells for a $2 \times 151$ cycles pairedend runs. Raw FASTQ reads were filtered using the computational pipeline described in Pawlowski et al. (2014a, 2014b) with the stringent parameters employed in Pochon et al. (2015). The analysis pipeline used for OTUs delineation and annotation is specifically tailored to account for the rates of evolution and 18S rRNA intragenomic variation that can be measured within and among foraminiferal lineages (Lejzerowicz et al., 2014; Pawlowski et al., 2014b). Quality filtered sequences were demultiplexed, paired-end assembled, and de-replicated into unique sequences. The unique sequences were then compared to an in-house foraminiferal database and clustered into Operational Taxonomic Units (OTUs), following the same procedure and parameters as in Pochon et al. (2015). The reference database, owned by Prof. Pawlowski at the University of Geneva, is a manually curated database resulting from more than 25 years of research (Pawlowski et al., 2014b) and now contains 1084 non-redundant and phylogenetically annotated 
sequences obtained from morphologically characterized individual single cells representing all currently identified foraminiferal taxa. To minimize incorporation of artefactual OTUs due to potential PCR and sequencing errors, foraminiferal OTUs not present in both the eDNA and eRNA datasets were removed. The raw FASTQ sequence data has been deposited in the Short Read Archive (BioProject PRJNA314935).

\subsection{Data analysis and statistics}

Untransformed numbers of reads per OTU were used to generate rarefaction curves using the Vegan package (Oksanen, 2015) in R software (R Core Team, 2015). Number of OTUs and species, Margalef diversity index, average taxonomic distinctness (taxonomic distance between any two organisms randomly chosen in a sample [AvTD]; Clarke and Warwick, 1998) and variation in taxonomic distinctness (variance between the AvTD pairwise path lengths [VarTD]; Clarke and Warwick, 2001) were calculated separately for each of the eDNA, eRNA and MCD datasets using the DIVERSE function implemented in PRIMER 7 (Clarke and Gorley, 2015). The relationship between diversity indices and distance from WHs was tested using a distancebased linear model (DistLM; Anderson, 2004), using the $\mathrm{R}^{2}$ selection criteria, and 9999 permutations. Previous research has shown that most macrofaunal environmental impact occurs within a $300 \mathrm{~m}$ radius from the WH (Ellis et al., 2012). To account for the non-linear relation of the pollution gradient over distance, distance was fourth root transformed.

Prior to further analysis, sequence abundance per OTU at each station was standardized and fourth root transformed; MCD data were also fourth root transformed, following Pochon et al. (2015). Bray-Curtis dissimilarity matrices (Clarke et al., 2001) were computed for each dataset (MCD, eDNA, and eRNA). 
Dissimilarities between stations were visualized using Principal Coordinate Ordination plots. The relationship between community structure with distance from WHs was tested using DistLM as described above and compared between datasets.

Key OTUs that varied in abundance along the impact gradient from WHs were examined with PRIMER 7, using a shade plot of the 20 most abundant OTUs in the eRNA dataset. Taxa with a Pearson correlation over $|0.35|$ with distance from WHs were retained as potential sensitive or opportunistic species. Once foraminiferal indicators were identified, their relative abundance were displayed over the PCO analysis of the environmental variables, based on Euclidean distance similarity matrix using PERMANOVA+ add-on (PRIMER-E Ltd.) in PRIMER 7. 


\section{Results}

\subsection{Foraminiferal assemblages}

3.1.1 Clustering of operational taxonomic units

Of the samples ( $n=51)$ co-extracted for eDNA/eRNA, 13 failed to PCR amplify for both eDNA and eRNA of a given sample, while two other samples did not amplify for either the eDNA or eRNA sample, despite multiple PCR trials using serial dilutions of starting eDNA/eRNA material and adding bovine serum albumin (BSA) to minimize inhibition effects (Table S1). The Illumina ${ }^{\mathrm{TM}}$ MiSeq sequencing run contained a total of 162 eDNA/eRNA amplicons, including 88 amplicons that belonged to another project and which were therefore excluded from the present study. The raw number of reads for the complete sequencing run was $3,718,088$ and $3,482,668$ for the eDNA and eRNA libraries, respectively. These sequence volumes were reduced by $1.3 \%$ and $1.34 \%$ for the eDNA and eRNA data sets respectively as a result of a low quality, by $24.3 \%$ and $26.2 \%$ due to poor matching positions in the partial overlap of assembled read pairs, by $14.6 \%$ and $13.7 \%$ because the primer sequences could not be matched and by $3.2 \%$ and $2.9 \%$ that corresponded to unexpected tagged primers pairs (Table S6). From the successfully amplified products $(n=74), 431,469$ eDNA reads and 319,954 represented by 136 OTUs remained for downstream analysis after quality filtering and removal of OTUs not present in both eDNA/eRNA datasets. Rarefaction curves indicated that the sampling effort was sufficient to correctly assess species richness in each sample (Figure S1).

\subsubsection{Taxonomic assignment}

Three main foraminiferal taxonomic groups were identified; monothalamids dominated eDNA (88\%) and eRNA (75\%), followed by the two newly assigned multi-chambered classes globothalamids and tubothalamids (Pawlowski et al., 2013; Figure S2). A small proportion of 
eDNA (3\%) and eRNA (4\%) OTUs could not be assigned to a specific foraminiferal group. These unassigned OTUs corresponded to groups of Independent Sequence Units (ISUs) that shared less than $80 \%$ similarity with every sequence of the reference database.

\subsection{Foraminifera and metazoans response to drilling activities}

The OTU/species richness and Margalef diversity index were lowest near the WH stations (Table 1), with the lowest OTUs richness found at Oi-2 WH ( $\mathrm{n}=10$ for eDNA, and 13 for eRNA) and at Oi-2 N100 ( $\mathrm{n}=14$ for eDNA/eRNA), and lowest species richness (MCD) observed at Oi-1 WH (n=7) and Oi-2 WH (n=12; Table S7). Taxonomic distinctness indices (AvTD and VarTD) did not show strong trends for either RNA or MCD datasets. Significant but weak relationships among distance from $\mathrm{WHs}$ for OTU/species richness (eRNA: $\mathrm{P}=0.02, \mathrm{R}^{2}=0.31$; eDNA: $\mathrm{P}=0.01, \mathrm{R}^{2}=0.21 ; \mathrm{MCD}: \mathrm{P}=<0.01, \mathrm{R}^{2}=0.27$ ) and Margalef diversity index (eRNA: $\mathrm{P}=0.04, \mathrm{R}^{2}=0.28$; eDNA: $\mathrm{P}=0.01, \mathrm{R}^{2}=0.21 ; \mathrm{MCD}: \mathrm{P}=<0.01, \mathrm{R}^{2}=0.27$ ) were identified with DistLM (Table S8). Apart from a weak, yet significant relationship between eDNA and Lambda+ $\left(\mathrm{P}=0.02, \mathrm{R}^{2}=0.18\right)$, no significant relationship could be observed with AvTD and VarTD. Overall, diversity indices derived from the eRNA dataset showed the strongest correlations with the spatial gradient, followed by MCD and eDNA, respectively (Table 1).

DistLM analysis between the Bray-Curtis dissimilarity matrices of foraminiferal assemblages and distance from WHs identified a very weak relationship for both eDNA ( $\mathrm{P}=0.02$, $\left.\mathrm{R}^{2}=0.06\right)$ and eRNA $\left(\mathrm{P}<0.01, \mathrm{R}^{2}=0.11\right)$ (Table $\mathrm{S} 8$ ). A similar pattern was observed with macrofaunal communities $\left(\mathrm{P}<0.01, \mathrm{R}^{2}=0.15\right)$.

Because the strongest relationships were observed using the eRNA dataset (Table 1 and S8) all further analysis was undertaken using these data only. The PCO for foraminiferal assemblages showed a clear separation between Oi-2 WH samples and all other stations (Figure 
2A). Foraminiferal assemblages at the Oi-1 WH clustered among the majority of other samples, including control sites (Figure 2A). In contrast, the MCD data formed two distinct clusters, one including both WH stations (Oi-1 and Oi-2) and the other including all other stations (Figure 2B). Overall, foraminiferal eRNA data displayed higher variability between replicates than the MCD (Figure 2A and 2B).

\subsection{Foraminiferal indicators of impact gradient}

Investigation of key foraminiferal OTUs associated with specific regions of the environmental impact gradient using a shade plot (Figure 3) and a Pearson correlation $(>|0.35|$ : Table S9) of the 20 most abundant OTUs allowed identification of eight taxa that were identified as either positively or negatively impacted by drilling activities. The relative abundance of eRNA reads decreased substantially with distance from WHs for the four following taxa: Bathysiphon sp.1 (OTU 32, $r=-0.61$ ), two unidentified globothalamids (OTU 226, $r=-0.52$ and OTU 234, $r$ $=-0.39$ ), and an unidentified monothalamid (OTU 313, $r=-0.46)$. In contrast, Reophax sp. (OTU 23, $r=0.48$ ), the unidentified monothalamid OTUs 73 (clade Enfor9 [Pawlowski et al. 2014b], $r$ $=0.39), 145(r=0.44)$ and $297(r=0.59)$ progressively increased in prevalence, especially when the distance from $\mathrm{WH}$ was $>100$ to $250 \mathrm{~m}$.

The PCO analysis highlighted differences in environmental parameters between the WHs and other stations (Figure 4). In particular, grain size composition was coarser and $\mathrm{Ba}$ and $\mathrm{As}$ concentrations higher at the WHs. Oi-2 WH had the lowest AFDW concentration and coarsest grain size of all stations, while Oi-1 WH contained the highest concentrations of $\mathrm{Pb}, \mathrm{Ni}, \mathrm{Zn}, \mathrm{Mn}$ and $\mathrm{Cu}$. The other stations contained higher levels of $\mathrm{Cr}$ and $\mathrm{Cd}$ compared to the WHs.

Of the selected species (Figure 3) with a decreasing abundance from the WHs, Bathysiphon sp.1 (OTU 32) and the unidentified globothalamid (OTU 234) were present at both 
WHs while the unidentified globothalamid (OTU 226) and monothalamid (OTU 313) only occurred at Oi-2 WH (Figure 4). For the key taxa associated with increasing relative abundance from WHs, Reophax sp. (OTU 23) and the unidentified monothalamid OTUs 73, 297 were absent from both WHs. The monothalamid OTU 145 was present at Oi-1 WH but absent from Oi-2 WH. 


\section{Discussion}

Current methods for assessing benthic impacts at offshore oil and gas drilling operation sites are costly and time consuming (collection and morphological sorting). They focus primarily on macrofaunal species and are therefore non-optimal for use in bathysmal (ca. $180 \mathrm{~m}$ to $1800 \mathrm{~m}$ ) and deep-sea monitoring (International Association of Oil and Gas Producers [OGP], 2012) where these organisms are often scarce and very patchily distributed (Brandt et al., 2014; Gage, 2004; Vrijenhoek, 2009). Molecular techniques could provide a suitable alternative to ensure appropriate environmental controls are in place as offshore mining activities expand. Foraminiferal metabarcoding is particularly appealing as it can be easily applied on small sediment samples using highly-specific primers and a well annotated database to rapidly and automatically characterize entire assemblages of foraminifera from a large variety of marine ecosystems. Foraminifera are abundant in the marine environment, and their small size, ubiquity, and rapid response to a large spectrum of marine pollutants make them excellent candidates as bioindicators around oil and gas drilling sites (Denoyelle et al., 2012; Frontalini and Coccioni, 2011).

\subsection{Response of foraminiferal versus macrofaunal assemblages}

To thoroughly evaluate the response of foraminifera and macrofauna towards the effect of drilling activities, it is important to understand the nature and extent of the environmental impact at and around WH sites. In Skilton et al. (2015), environmental variables (PAH, TPH and heavy metals) monitored at the Oi sites were found to be under the low values (10\% chance to observe biological effect) of the Interim Sediment Quality Guidelines (ISQG) defined in Australia and New Zealand Guidelines for Fresh Water and Marine Water Quality (ANZECC, 2000). The only station used in the present study that had values equal to or slightly higher than the ISQG was Oi- 
$1 \mathrm{WH}$ (21 mg of Ni/kg; Skilton et al., 2015). Furthermore, sediment PAH and TPH concentrations were below analytical detection levels for all Oi stations (Skilton et al., 2015). Although elevated concentration of barium could be found up to $1000 \mathrm{~m}$ away from WHs, only stations located inside the $250 \mathrm{~m}$ perimeter appeared strongly impacted, showing higher concentration of arsenic, coarser sediment, lower organic content and hypoxic condition at the WHs (Skilton et al., 2015).

Despite the weak and spatially limited environmental impact of drilling activities, diversity indices of foraminiferal and macrofaunal assemblages demonstrated a significant correlation with increasing distance from WHs (Table 1). This suggests that foraminifera, similar to macrofauna, are sensitive to the impact of drilling activities, corroborating the findings of previous studies (Denoyelle et al., 2010; Duchemin et al., 2008; Durrieu et al., 2006; Jorissen et al., 2009; Mojtahid et al., 2006).

In this investigation, we hypothesized that foraminiferal (eDNA/eRNA) assemblages would be more sensitive than macrofaunal assemblages towards drilling activities. However, a similar response was observed with both groups (Figure 2; Table S8).

As none of the metals were present in sufficient concentration to cause significant toxicological effects (Skilton et al., 2015), the differences in macrofaunal assemblages among sites was likely due to the hypoxic condition caused by the rapid degradation of organic material, and the sedimentation of drill cuttings near the WHs. Macrobenthic density and diversity are known to be strongly affected by low oxygen concentration, with macrofauna being progressively replaced by meiobenthic organisms in such conditions (Dauer, 1993; Diaz and Rosenberg, 1995; Josefson and Widbom, 1988; Levin, 2001).

Conversely, many foraminiferal species seem tolerant to relatively low oxygen 
concentration (Jorissen et al., 2007; Langlet et al., 2014; Murray, 2001). However, changes in grain size of sediment may have played an important role in causing the lower OTU richness and different community structure found at the Oi2 WH. Several investigations have observed a substantial effect of grain size on hard-shell foraminiferal communities although results differ (e.g. Armynot du Châtelet et al., 2004; Diz et al., 2004; Hayward et al., 1996). For example, Diz et al. (2004) found larger and more diverse foraminiferal population on sandy grain size in a shallow marine embayment whereas Armynot du Châtelet et al. (2009) found greater diversity and abundance on muddy sediment in a similar type of environment. For soft-shell foraminifera, Gooday (2002) observed that fine sediment appears to increase their diversity and abundance in cold and tranquil settings (e.g. deep sea, fjords, and some polar environments). This corroborates our results where the presence of coarser sediment seemed to adversely impact OTUs richness near the WHs.

A notable difference between macrofaunal and foraminiferal assemblages at WHs was that foraminiferal assemblages at the Oi-1 WH did not diverge from more distant sites, whereas macrofaunal assemblages at Oi-1 and Oi-2 WHs differed markedly from all other sites. Apart from the possible effect of grain size, a plausible explanation is that at the time of sample collection at Oi-1 stations, a one-month period had passed since drilling activities. Many species of benthic foraminifera complete their life cycle within 2 weeks (Lee et al., 1991) making it possible that they had already recolonized the area affected by the drill cuttings. Although some foraminifera (especially larger and/or deep-sea species) may live up to 2 years (Boltovskoy and Wright, 1976), their relatively short generation time compared with most macrofaunal organisms likely provides an accurate indication of the current state of a site, and this may be an extremely valuable attribute when making environmental assessments. This assumption is also supported by 
Alve (1999) who asserts that in high energy environment (bottom current over $20 \mathrm{~cm} / \mathrm{s}$ ), foraminiferal recolonization of habitat can happen within few days. In low energy environment (bottom current below $10 \mathrm{~cm} / \mathrm{s}$ ), habitat recovery follows the typical metazoan successional pattern (appearance of pioneer and opportunistic species followed by more specialized species), which can take up to several years. On Oi sites, the bottom current energy is considered to be intermediate (around $7 \mathrm{~cm} / \mathrm{s}$ to $26 \mathrm{~cm} / \mathrm{s}$ for most of the time: Govier and Calder, 2013) and therefore, a slightly faster recovery of foraminiferal communities would be expected.

Environmental RNA showed stronger correlations with the pollution gradients than eDNA (Tables 1 and S8). This observation is consistent with results obtained by Pochon et al. (2015) and Dowle et al. (2015a) and is most likely because eRNA typically provides information on the active proportion of the community (Stoeck et al., 2007). Conversely, eDNA can be composed of significant amount of extracellular DNA, mirroring former foraminiferal assemblages that were present under different environmental conditions (Novitsky, 1986). With foraminifera, this can be particularly problematic as their tests tend to accumulate in sediment over time. For this reason, the Foraminiferal Bio-Monitoring initiative (FOBIMO; Schönfeld et al., 2012) suggests using living assemblages via rose Bengal staining techniques (Walton, 1952) when performing monitoring surveys. Although eRNA likely represents a better proxy for assessing actual living organisms than eDNA and should be prioritized when performing molecular monitoring, careful preservation and storage of RNA is necessary to avoid degradation. Additional processing time and costs (e.g. reverse trancriptase) are greater than with eDNA samples. Further studies are therefore needed to evaluate the pros and cons of using eDNA versus eRNA. 
In general, foraminiferal metabarcoding communities within replicates were more variable than macrofaunal assemblages. A total of $31 \%$ of the eDNA and eRNA samples failed to amplify in spite of appropriate measures (serial dilutions of starting eDNA/eRNA templates, and addition of BSA) taken to minimize potential inhibition effects of compounds found in these sediment samples. We cannot exclude the possibility that the failed amplifications are the result of a degradation of sample quality during transport to the laboratory, although an ongoing study using the same samples to amplify bacteria and other eukaryotic organisms (Laroche et al. unpublished) indicates that the lack of amplification is limited to only a few of these samples (data not shown). Variation within replicates and the possibility that foraminifera were absent from some of our samples suggest heterogeneity of foraminiferal distribution in deeper-water. Many studies using micropaleontological (Barras et al., 2010; Bernstein and Meador, 1979; Cornelius and Gooday, 2004; Fontanier et al., 2003; Griveaud et al., 2010; Lynts, 1966; Schafer, 1971) and metabarcoding (Lejzerowicz et al., 2014) methods in shallow and deep marine water have observed high natural variability in foraminiferal composition. However, the micropatchiness found in our study contrasts with patterns observed by Pawlowski et al. (2014a) and Pochon et al. (2015) who used foraminiferal metabarcoding at fish farms (15 to $40 \mathrm{~m}$ depth), and showed little within site variability. Additionally, they were able to obtain PCR amplicons for all eDNA/eRNA samples. Heterogeneity in benthic communities results from a combination of variations in sediment characteristics, current flow, and biological relationships (Grassle and Grassle, 1994; Schafer, 1973; Thiel et al., 1989). In conditions of environmental stability, Schafer (2000) observed that biological interactions displace the effect of physical parameters, resulting in increased spatial variability of foraminiferal distribution. Sampling of a larger surface area per site may assist in reducing the observed 'patchiness'. 
For safety reasons, sampling stations near offshore platforms are rarely closer than $250 \mathrm{~m}$ from the wells, perimeter inside which most environmental impacts have been observed (Ellis et al., 2012). Therefore, monitored stations are usually characterized by a weak impact gradient and this is also at least partly responsible for the observed high heterogeneity in foraminiferal diversity within a site. In the present study sampling of an exploratory drilling site provided us with the unique opportunity to collect sediment at the WHs. However, exploratory sites are characterized by lesser environmental impacts than fully operational platforms due to shorter periods of drilling activities and absence of production operations.

\subsection{Foraminiferal indicators of environmental impact}

Analysis of the shade plots of the 20 most abundant OTUs (Figure 3) allowed the identification of 8 taxa that showed consistent responses to drilling activities. Taxa with the strongest correlation $(r>|0.5|)$ with distance from WHs were, in decreasing order, Bathysiphon sp.1 (OTU 32, $r=-0.61$ ), the unidentified monothalamid (OTU 297, $r=0.59$ ) and the unidentified globothalamids (OTU 226, $r=-0.52$ ).

Of the eight potential bioindicators, none could be identified to species level, and only two could be identified to genus level (Bathysiphon sp.1 [OTU 32] and Reophax sp. [OTU 23]). The difficulty in assigning foraminiferal OTUs to species level contrasts with the previous findings of Pochon et al. (2015) from shallow and sheltered water environments in the Marlborough sounds, and likely reflects the considerable lack of comparative genetic data available for foraminiferal assemblage in offshore habitats around New Zealand. As advocated in Drummond et al. (2015), increasing the number of markers could help provide a more comprehensive taxonomic signal. However, the few alternative markers that have been explored for foraminiferal metabarcoding (actin, tubulin, and ubiquitin) are too conserved to be useful for 
species-level analysis (Flakowski et al., 2006; Pawlowski and Holzmann, 2008; Pawlowski et al., 2014b). To date, the $18 \mathrm{~S}$ rRNA marker and the fully functional database and pipeline remain the most effective way for characterizing entire foraminiferal assemblages in marine sediment (Pawlowski et al., 2016), and it is therefore essential to keep characterizing new foraminiferal species and extending this valuable database.

The PCO analysis of environmental variables (Figure 4) showed some characteristic distinctions in OTUs relative eRNA abundance between the two WHs. Firstly, from the taxa identified as "tolerant", OTUs 32 and 234 were present at the two WHs, while OTUs 226 and 313 were absent from Oi-1 WH, possibly indicating sensitivity to high metal concentration or preference of coarser sediment. Secondly, OTUs 23, 73 and 297 classified as "sensitive" taxa were absent from both WHs, indicating strong sensitivity to sediment perturbation and/or metal concentration. In contrast, OTU 145 was absent from Oi-2 WH, but present at Oi-1 WH, suggesting possible responsiveness to changes in grain size. Despite the clear dominance of monothalamid foraminiferal OTUs in benthic marine ecosystems (Lecroq et al. 2011; Pawlowski et al. 2014a; Pochon et al. 2015) and the particularly good response of monothalamids to perturbation (e.g., OTUs 73, 145, and 297; this study), this is an important group of foraminifera which diversity has been largely unexplored (Pawlowski et al. 2014b). A PhD project focusing on the morphological and molecular characterization of monothalamids is currently underway in the Pawlowski's lab (Pawlowski, pers. comm.), which may provide valuable information for future work.

Without further taxonomic information on OTUs 73, 145, 226, 234, 297 and 313, comparison with known ecological information on these taxa is not possible. Bathysiphon species are well-known for occupying deposit-feeding niches (Landing et al., 2012). Because they mainly 
feed on detritus and bacteria (Duffield et al., 2014) this may give them the ability to thrive in low organic content conditions such as those observed near the WHs. Bathysiphon tests are made of agglutinated material (micaceous scales or quartz grains) instead of calcium carbonate (Cole and Valentine, 2006; Sen Gupta, 2002). This may render Bathysiphon species less susceptible to dissolution due to the high concentration of $\mathrm{H}_{2} \mathrm{~S}$ and low $\mathrm{pH}$ conditions occurring near drilling platforms, although additional studies will be required to test this hypothesis. Members of the agglutinated morphogroup, Reophax spp. display small and elongated physiology, and have been previously characterized as infaunal opportunists by Kaminski et al. $(1995,1988)$. It is therefore surprising to observe a negative correlation of their relative abundance with proximity from WHs.

While the high relative abundance of specific OTUs may indicate tolerance towards drilling activities, it could also result from increased stress through enhanced reproduction (Ernst et al., 2006). Therefore, caution must prevail before asserting the actual effect of drilling operations on the selected taxa.

It is imperative that additional comparable surveys be carried out in order to confirm the relevance of these OTUs as accurate proxies of environmental impacts from marine drilling operations. Efforts to supplement reference database with samples from the Taranaki Basin would also assist in improving taxonomic assignments. 


\section{Conclusion}

Metabarcoding offers significant potential for reducing the costs and processing time associated with identification of benthic biota at offshore mining sites. Foraminifera are important members of benthic ecosystems, being sensitive to environmental changes, and possessing short life cycles. Monitoring their communities provides a number of advantages over benthic macrofauna and their fossilization potential allow for pre-pollution assessment when no baseline data is available.

In this study, morphologically identified macrofauna, and genetically identified foraminiferal assemblages (eDNA/eRNA) showed similar responses to drilling activities, with the main difference occurring at the Oi-1 well. This probably occurs because of differences in grain size and of the shorter generation time of foraminifera. This highlights how different taxa and techniques can provide complementary information that enables a holistic overview of current and previous impacts at a site. Within site variability was greater for foraminifera and suggests the need to adapt sampling methodologies to account for the natural patchiness found at these relatively deep and low-impacted environments.

The eRNA displayed slightly better relationships with environmental variables and may be a better proxy for understanding the current level of impact - further studies are required to confirm this. Eight taxa were identified as potential indicators of a perturbation gradient, of which, five could be identified to genus level. While additional spatio-temporal studies will be critical to ascertain the use of these OTUs as accurate indicators, our results also highlight the need to improve the reference sequence databases. These databases will assist in improving taxonomic assignment through formal taxonomic descriptions of new assemblages from understudied environments. Metabarcoding investigation of bacterial and other eukaryotic meiofaunal communities from additional oil fields in Taranaki are underway (Laroche et al., 
unpublished) and may provide helpful information to enhance knowledge of the effects of offshore mining activities and to develop a comprehensive and robust multi-taxa monitoring tool. 


\section{Acknowledgements}

We would like to express our gratitude to Resource and Environmental Management Ltd (Nelson, NZ) and Simon Knapman from AWE Ltd for providing the samples and for in-kind support. This research was co-funded by the Cawthron Institute Internal Investment Fund (IIF \#15955) and the "Fonds de Recherche du Québec - Natures et Technologies" as part of a doctoral research scholarship (grant ID\#184395). This study was supported by the Swiss National Science Foundations grants 31003A-159709 and 316030-150817. 


\section{References}

Alve, E., 1999. Colonization of new habitats by benthic foraminifera: a review. Earth-Science Rev. 46, 167-185. doi:10.1016/S0012-8252(99)00016-1

Anderson, M.J., 2004. DISTLM v. 5: a FORTRAN computer program to calculate a distancebased multivariate analysis for a linear model. Dep. Stat. Univ. Auckland, New Zeal. 10.

ANZECC, 2000. An Introduction to the Australian and New Zealand Guidelines for Fresh and Marine Water Quality, National Water Quality Management Strategy. Canberra.

Armynot du Châtelet, É., Bout-Roumazeilles, V., Riboulleau, A., Trentesaux, A., 2009. Sediment (grain size and clay mineralogy) and organic matter quality control on living benthic foraminifera. Rev. Micropaleontol. 52, 75-84. doi:10.1016/j.revmic.2008.10.002

Armynot du Châtelet, É., Debenay, J.-P., Soulard, R., 2004. Foraminiferal proxies for pollution monitoring in moderately polluted harbors. Environ. Pollut. 127, 27-40. doi:10.1016/S02697491(03)00256-2

Baird, D.J., Hajibabaei, M., 2012. Biomonitoring 2.0: a new paradigm in ecosystem assessment made possible by next-generation DNA sequencing. Mol. Ecol. 21, 2039-2044. doi:DOI 10.1111/j.1365-294X.2012.05519.x

Barras, C., Fontanier, C., Jorissen, F.J., Hohenegger, J., 2010. A comparison of spatial and temporal variability of living benthic foraminiferal faunas at $550 \mathrm{~m}$ depth in the Bay of Biscay. Micropaleontology 56, 275-295.

Bergin, F., Kucuksezgin, F., Uluturhan, E., Barut, I.F., Meric, E., Avsar, N., Nazik, A., 2006. The response of benthic foraminifera and ostracoda to heavy metal pollution in Gulf of Izmir (Eastern Aegean Sea). Estuar. Coast. Shelf Sci. 66, 368-386. doi:10.1016/j.ecss.2005.09.013

Bernstein, B.B., Meador, J.P., 1979. Temporal persistence of biological patch structure in an abyssal benthic community. Mar. Biol. 51, 179-183. doi:10.1007/BF00555197

Boltovskoy, E., Wright, R., 1976. Recent Foraminifera, Igarss 2014. Springer Netherlands, Dordrecht. doi:10.1007/978-94-017-2860-7

Borja, Á., Rodríguez, J.G., Black, K., Bodoy, A., Emblow, C., Fernandes, T.F., Forte, J., Karakassis, I., Muxika, I., Nickell, T.D., Papageorgiou, N., Pranovi, F., Sevastou, K., Tomassetti, P., Angel, D., 2009. Assessing the suitability of a range of benthic indices in the evaluation of environmental impact of fin and shellfish aquaculture located in sites across Europe. Aquaculture 293, 231-240. doi:10.1016/j.aquaculture.2009.04.037

Bourlat, S.J., Borja, A., Gilbert, J., Taylor, M.I., Davies, N., Weisberg, S.B., Griffith, J.F., Lettieri, T., Field, D., Benzie, J., Glöckner, F.O., Rodríguez-Ezpeleta, N., Faith, D.P., Bean, T.P., Obst, M., 2013. Genomics in marine monitoring: New opportunities for assessing marine health status. Mar. Pollut. Bull. 74, 19-31. doi:10.1016/j.marpolbul.2013.05.042

Brandt, A., Griffiths, H., Gutt, J., Linse, K., Ballerini, T., Danis, B., Pfannkuche, O., 2014. Challenges of deep-sea biodiversity assessments in the Southern Ocean. Adv. Polar Sci. 25, 204-212. doi:10.13679/j.advps.2014.3.00204

Casey, R., Amos, A., Anderson, J., Koehler, R., Schwarzer, R., Sloan, J., 1980. A preliminary report on the microplankton and microbenthon responses to the 1979 gulf of Mexico oil 
spills (IXTOC I and Burmah Agate), with comments on avenues of oil to the sediments and the fate of oil in the column and on the bottom. Trans. Coast Assoc. Geol. Soc. 30, 273-281.

Clarke, K.R., Gorley, R.N., 2015. PRIMER v7: User Manual/Tutorial. Plymouth.

Clarke, K.R., Gorley, R.N., Somerfield, P.J., Warwick, R.M., 2001. Change in marine communities: An approach to statistical analysis and interpretation, 3rd ed. PRIMER-E Ltd, Plymouth.

Clarke, K.R., Warwick, R.M., 2001. A further biodiversity index applicable to species lists: Variation in taxonomic distinctness. Mar. Ecol. Prog. Ser. 216, 265-278. doi:10.3354/meps 216265

Clarke, K.R., Warwick, R.M., 1998. A taxonomic distinctness index and its statistical proprieties. J. Appl. Ecol. doi:10.1046/j.1365-2664.1998.3540523.x

Cornelius, N., Gooday, A.J., 2004. "Live" (stained) deep-sea benthic foraminiferans in the western Weddell Sea: Trends in abundance, diversity and taxonomic composition along a depth transect. Deep. Res. Part II Top. Stud. Oceanogr. 51, 1571-1602. doi:10.1016/j.dsr2.2004.06.024

Cristescu, M.E., 2014. From barcoding single individuals to metabarcoding biological communities: towards an integrative approach to the study of global biodiversity. Trends Ecol. Evol. 29, 566-571. doi:10.1016/j.tree.2014.08.001

Dauer, D.M., 1993. Biological criteria, environmental health and estuarine macrobenthic community structure. Mar. Pollut. Bull. 26, 249-257. doi:10.1016/0025-326X(93)90063-P

Denoyelle, M., Geslin, E., Jorissen, F.J., Cazes, L., Galgani, F., 2012. Innovative use of foraminifera in ecotoxicology: A marine chronic bioassay for testing potential toxicity of drilling muds. Ecol. Indic. 12, 17-25. doi:10.1016/j.ecolind.2011.05.011

Denoyelle, M., Jorissen, F.J., Martin, D., Galgani, F., Miné, J., 2010. Comparison of benthic foraminifera and macrofaunal indicators of the impact of oil-based drill mud disposal. Mar. Pollut. Bull. 60, 2007-2021. doi:10.1016/j.marpolbul.2010.07.024

Diaz, R.J., Rosenberg, R., 1995. Marine benthic hypoxia: A review of its ecological effects and the behavioural responses of benthic macrofauna. Oceanogr. Mar. Biol. an Annu. Rev. 33, 245-303.

Diz, P., 2004. Distribution of benthic foraminifera in coarse sediments, ria de Vigo, NW Iberian margin. J. Foraminifer. Res. 34, 258-275. doi:10.2113/34.4.258

Dowle, E., Pochon, X., Keeley, N., Wood, S.A., 2015a. Assessing the effects of salmon farming seabed enrichment using bacterial community diversity and high-throughput sequencing. FEMS Microbiol. Ecol. 91, fiv089. doi:10.1093/femsec/fiv089

Dowle, E., Pochon, X., Banks, J., Shearer, K., Wood, S.A., 2015b. Targeted gene enrichment and high throughput sequencing for environmental biomonitoring: a case study using freshwater macroinvertebrates. Mol. Ecol. Resour. n/a-n/a. doi:10.1111/1755-0998.12488

Drummond, A.J., Newcomb, R.D., Buckley, T.R., Xie, D., Dopheide, A., Potter, B.C., Heled, J., Ross, H.A., Tooman, L., Grosser, S., Park, D., Demetras, N.J., Stevens, M.I., Russell, J.C., Anderson, S.H., Carter, A., Nelson, N., 2015. Evaluating a multigene environmental DNA 
approach for biodiversity assessment. Gigascience 4, 46. doi:10.1186/s13742-015-0086-1

Duchemin, G., Mojtahid, M., Bicchi, E., Gaultier, M., Jorissen, F.J., D’Yeu, I., Durrieu, J., Galgani, F., Cazes, L., Camps, R., 2008. A new monitoring tool for assessing environmental impact of offshore drilling activities: Benthic foraminifera. Soc. Pet. Eng. - 9th Int. Conf. Heal. Saf. Environ. Oil Gas Explor. Prod. 2008 - "In Search Sustain. Excell. 4, 1992-2003. doi:10.2118/111959-MS

Duffield, C.J., Edvardsen, B., Eikrem, W., Alve, E., 2014. Effects of different potential food sources on upper-bathyal benthic foraminifera: an experiment with propagules. J. Foraminifer. Res. 44, 416-433. doi:10.2113/gsjfr.44.4.416

Durrieu, J., Mojtahid, M., Cazes, L., Galgani, F., Jorissen, F., Tran, D., Camps, R., 2006. Aged drilled cuttings offshore Gabon: new methodology for assessing their impact, in: SPE International Health, Safety \& Environment Conference. Society of Petroleum Engineers, Abu Dhabi, p. 8. doi:10.2118/98414-MS

Ellis, J.I., Fraser, G., Russell, J., 2012. Discharged drilling waste from oil and gas platforms and its effects on benthic communities. Mar. Ecol. Prog. Ser. 456, 285-302. doi:10.3354/meps09622

Ernst, S.R., Morvan, J., Geslin, E., Le Bihan, a., Jorissen, F.J., 2006. Benthic foraminiferal response to experimentally induced Erika oil pollution. Mar. Micropaleontol. 61, 76-93. doi:10.1016/j.marmicro.2006.05.005

Fernandes, T.F., Eleftheriou, A., Ackefors, H., Eleftheriou, M., Ervik, A., Sanchez-Mata, A., Scanlon, T., White, P., Cochrane, S., Pearson, T.H., Read, P.A., 2001. The scientific principles underlying the monitoring of the environmental impacts of aquaculture. J. Appl. Ichthyol. 17, 181-193. doi:10.1046/j.1439-0426.2001.00315.x

Flakowski, J., Bolivar, I., Fahrni, J., Pawlowski, J., 2006. Tempo and mode of spliceosomal intron evolution in actin of foraminifera. J. Mol. Evol. 63, 30-41. doi:10.1007/s00239-0050061-z

Fontanier, C., Jorissen, F.J., Chailloua, G., David, C., Anschutz, P., Lafon, V., 2003. Seasonal and interannual variability of benthic foraminiferal faunas at $550 \mathrm{~m}$ depth in the Bay of Biscay. Deep. Res. Part I Oceanogr. Res. Pap. 50, 457-494. doi:10.1016/S09670637(02)00167-X

Frontalini, F., Coccioni, R., 2011. Benthic foraminifera as bioindicators of pollution: A review of Italian research over the last three decades. Rev. Micropaléontologie 54, 115-127. doi:10.1016/j.revmic.2011.03.001

Gage, J.D., 2004. Diversity in deep-sea benthic macrofauna: The importance of local ecology, the larger scale, history and the Antarctic. Deep. Res. Part II Top. Stud. Oceanogr. 51, 16891708. doi:10.1016/j.dsr2.2004.07.013

Gooday, A.J., 2002. Organic-walled Allogromids: aspects of their occurance, diversity and ecology in marin habitats. J. Foraminifer. Res. 32, 384-399. doi:10.2113/0320384

Govier, D., Calder, S., 2013. Impact Assessment (No. AWENZ-RPT-1304). Nelson.

Grassle, J.F., Grassle, J.P., 1994. Notes from the abyss: the effects of a patchy supply of organic material and larvae on soft-sediment benthic communities, in: Aquatic Ecology, Scale, 
Pattern and Process, 34th Symposium of the British Ecological Society. Blackwell Scientific, Oxford.

Griveaud, C., Jorissen, F., Anschutz, P., 2010. Spatial variability of live benthic foraminiferal faunas on the portuguese margin. Micropaleontology 56, 297-322.

Hayward, B.W., Grenfell, H., Cairns, G., Smith, a., 1996. Environmental controls on benthic foraminiferal and thecamoebian associations in a New Zealand tidal inlet. J. Foraminifer. Res. 26, 150-171. doi:10.2113/gsjfr.26.2.150

Hayward, B.W., Grenfell, H.R., Nicholson, K., Parker, R., Wilmhurst, J., Horrocks, M., Swales, A., Sabaa, A.T., 2004. Foraminiferal record of human impact on intertidal estuarine environments in New Zealand's largest city. Mar. Micropaleontol. 53, 37-66. doi:10.1016/j.marmicro.2004.03.001

Hess, S., Alve, E., Trannum, H.C., Norling, K., 2013. Benthic foraminiferal responses to waterbased drill cuttings and natural sediment burial: Results from a mesocosm experiment. Mar. Micropaleontol. 101, 1-9. doi:10.1016/j.marmicro.2013.03.004

International Association of Oil and Gas Producers, 2012. Offshore environmental monitoring for the oil \& gas industry. Author. Retrieved from: http://www.ogp.org.uk/pubs/457.pdf

International Energy Agency (IEA), 2012. Golden Rules for a Golden Age of Gas, World Energy Outlook Special Report. Paris: Author. Retrieved from:

http://www.worldenergyoutlook.org/media/weowebsite/2012/goldenrules/weo2012_goldenr ulesreport.pdf (October 15, 2015)

Ji, Y., Ashton, L., Pedley, S.M., Edwards, D.P., Tang, Y., Nakamura, A., Kitching, R., Dolman, P.M., Woodcock, P., Edwards, F. a., Larsen, T.H., Hsu, W.W., Benedick, S., Hamer, K.C., Wilcove, D.S., Bruce, C., Wang, X., Levi, T., Lott, M., Emerson, B.C., Yu, D.W., 2013. Reliable, verifiable and efficient monitoring of biodiversity via metabarcoding. Ecol. Lett. 16, 1245-1257. doi:10.1111/ele.12162

Johnston, O., Barter, P., Ellis, J., Elvines, D., 2014. Recommandations for an offshore Taranaki environmental monitoring protocol: Drilling and production related discharges (Cawthron Report No. 2124): Cawthron Institute

Jorissen, F.J., Bicchi, E., Duchemin, G., Durrieu, J., Galgani, F., Cazes, L., Gaultier, M., Camps, R., 2009. Impact of oil-based drill mud disposal on benthic foraminiferal assemblages on the continental margin off Angola. Deep Sea Res. Part II Top. Stud. Oceanogr. 56, 2270-2291. doi:10.1016/j.dsr2.2009.04.009

Jorissen, F.J., Fontanier, C., Thomas, E., 2007. Chapter seven: Paleoceanographical proxies based on deep-sea benthic foraminiferal assemblage characteristics. Dev. Mar. Geol. 1, 263325. doi:10.1016/S1572-5480(07)01012-3

Josefson, a. B., Widbom, B., 1988. Differential response of benthic macrofauna and meiofauna to hypoxia in the Gullmar Fjord basin. Mar. Biol. 100, 31-40. doi:10.1007/BF00392952

Kaminski, M.A., Boersma, A., Tyszka, J., Holbourn, A.E.L., 1995. Response of deep-water agglutinated foraminifera to dysoxic conditions in the California Borderland basins, in: Proceedings 4th International Workshop on Agglutinated Foraminifera, Krakow, 1993. pp. 131-140. 
Kaminski, M.A., Grassle, J.F., Whitlatch, R.B., 1988. Life history and recolonization among agglutinated foraminifera in the Panama Basin. Abhandlungen der Geol. Bundesanstalt 41, 229-243.

Landing, E., Reyes, S., Andreas, A., Bowser, S., 2012. First discovery of Early Palaeozoic Bathysiphon (Foraminifera)-test structure and habitat of a "living fossil." Geol. Mag. 149, 1013-1022. doi:http://dx.doi.org/10.1017/S0016756812000155

Langlet, D., Baal, C., Geslin, E., Metzger, E., Zuschin, M., Riedel, B., Risgaard-Petersen, N., Stachowitsch, M., Jorissen, F.J., 2014. Foraminiferal species responses to in situ, experimentally induced anoxia in the Adriatic Sea. Biogeosciences 11, 1775-1797. doi:10.5194/bg-11-1775-2014

Langlet, D., Geslin, E., Baal, C., Metzger, E., Lejzerowicz, F., Riedel, B., Zuschin, M., Pawlowski, J., Stachowitsch, M., Jorissen, F.J., 2013. Foraminiferal survival after long-term in situ experimentally induced anoxia. Biogeosciences 10, 7463-7480. doi:10.5194/bg-107463-2013

Lecroq, B., Lejzerowicz, F., Bachar, D., Christen, R., Esling, P., Baerlocher, L., Østerås, M., Farinelli, L., Pawlowski, J., 2011. Ultra-deep sequencing of foraminiferal microbarcodes unveils hidden richness of early monothalamous lineages in deep-sea sediments. Proc. Natl. Acad. Sci. U. S. A. 108, 13177-82. doi:10.1073/pnas.1018426108

Lee, J.J., Faber, W.W., Anderson, O.R., Pawlowski, J., 1991. Life cycles of foraminifera, in: Lee, J.J., Anderson, O.. (Eds.), Biology of Foraminifera. Academic Press, London, pp. 285-334.

Lejzerowicz, F., Esling, P., Pawlowski, J., 2014. Patchiness of deep-sea benthic Foraminifera across the southern ocean: Insights from High-throughput DNA sequencing. Deep Sea Res. Part II Top. Stud. Oceanogr. 108, 17-26. doi:10.1016/j.dsr2.2014.07.018

Lejzerowicz, F., Voltsky, I., Pawlowski, J., 2013. Identifying active foraminifera in the Sea of Japan using metatranscriptomic approach. Deep. Res. Part II Top. Stud. Oceanogr. 86-87, 214-220. doi:10.1016/j.dsr2.2012.08.008

Levin, L.A., 2001. Oxygen minimum zone: the effects of permanent hypoxia on bathyal ecosystems., in: Proceeding of the 6th International Symposium on Fish Physiology, Toxicology and Water Quality. pp. 22-26.

Lillis, L., Doyle, E., Clipson, N., 2009. Comparison of DNA- and RNA-based bacterial community structures in soil exposed to 2,4-dichlorophenol. J. Appl. Microbiol. 107, 18831893. doi:10.1111/j.1365-2672.2009.04369.x

Kaminski, M.A., Grassle, J.F., Whitlatch, R.B., 1988. Life history and recolonization among agglutinated foraminifera in the Panama Basin. Abhandlungen der Geol. Bundesanstalt 41, 229-243.

LYNTS, G.W., 1966. Variation of foraminiferal standing crop over short lateral distances in Buttonwood Sound, Florida Bay. Limnol. Oceanogr. 11, 562-566. doi:10.4319/1o.1966.11.4.0562

Mengoni, A., Tatti, E., Decorosi, F., Viti, C., Bazzicalupo, M., Giovannetti, L., 2005. Comparison of 16S rRNA and 16S rDNA T-RFLP approaches to study bacterial communities in soil microcosms treated with chromate as perturbing agent. Microb. Ecol. 
50, 375-384. doi:10.1007/s00248-004-0222-4

MetOcean Solutions Limited, 2013. Oil spill trajectory modelling - Assessment of potential coastal impacts with simulation of surface release from proposed well at Oi-1 (Report P0149-02). New Plymouth, Author.

Mojtahid, M., Jorissen, F., Durrieu, J., Galgani, F., Howa, H., Redois, F., Camps, R., 2006. Benthic foraminifera as bio-indicators of drill cutting disposal in tropical east Atlantic outer shelf environments. Mar. Micropaleontol. 61, 58-75. doi:10.1016/j.marmicro.2006.05.004

Mojtahid, M., Jorissen, F., Pearson, T.H., 2008. Comparison of benthic foraminiferal and macrofaunal responses to organic pollution in the Firth of Clyde (Scotland). Mar. Pollut. Bull. 56, 42-76. doi:10.1016/j.marpolbul.2007.08.018

Murray, J., 2006. Ecology and application of benthic foraminifera. Cambridge University Press, Cambridge.

Murray, J.W., 2001. The niche of benthic foraminifera, critical thresholds and proxies. Mar. Micropaleontol. 41, 1-7. doi:10.1016/S0377-8398(00)00057-8

Murray, J.W., 1986. Living and dead Holocene foraminifera of Lyme Bay, southern England. J. Foraminifer. Res. 16, 347-352. doi:10.2113/gsjfr.16.4.347

Novitsky, J.A., 1986. Degradation of dead microbial biomass in a marine sediment. Appl. Environ. Microbiol. 52, 504-509.

Oksanen, J., 2015. Multivariate analysis of ecological communities in R: vegan tutorial. Trends Ecol. Evol. 3, 121. doi:10.1016/0169-5347(88)90124-3

Organisation of the Petroleum Exporting Countries, 2014. World oil outlook: Author. Retrieved from:

https://www.opec.org/opec_web/static_files_project/media/downloads/publications/WOO_2 014.pdf (October 22, 2015)

Pawlowski, J., Esling, P., Lejzerowicz, F., Cedhagen, T., Wilding, T.A., 2014a. Environmental monitoring through protist NGS metabarcoding: assessing the impact of fish farming on benthic foraminifera communities. Mol. Ecol. Resour. 14, early online. doi:10.1111/17550998.12261

Pawlowski, J., Fontaine, D., da Silva, A.A., Guiard, J., 2011. Novel lineages of Southern Ocean deep-sea foraminifera revealed by environmental DNA sequencing. Deep Sea Res. Part II Top. Stud. Oceanogr. 58, 1996-2003. doi:10.1016/j.dsr2.2011.01.009

Pawlowski, J., Holzmann, M., 2008. Diversity and geographic distribution of benthic foraminifera: A molecular perspective. Biodivers. Conserv. 17, 317-328. doi:10.1007/s10531-007-9253-8

Pawlowski, J., Holzmann, M., Tyszka, J., 2013. New supraordinal classification of Foraminifera: Molecules meet morphology. Mar. Micropaleontol. 100, 1-10. doi:10.1016/j.marmicro.2013.04.002

Pawlowski, J., Lecroq, B., 2010. Short rDNA Barcodes for Species Identification in Foraminifera. J. Eukaryot. Microbiol. 57, 197-205. doi:10.1111/j.1550-7408.2009.00468.x

Pawlowski, J., Lejzerowicz, F., Apotheloz-Perret-Gentil, L., Visco, J., Esling, P., 2016. Protist 
metabarcoding and environmental biomonitoring: time for change. Eur. J. Protistol. doi:10.1016/j.ejop.2016.02.003

Pawlowski, J., Lejzerowicz, F., Esling, P., 2014b. Next-Generation Environmental Diversity Surveys of Foraminifera $\square$ : Preparing the Future. Biol. Bull. 227, 93-106.

Pochon, X., Wood, S.A., Keeley, N.B., Lejzerowicz, F., Esling, P., Drew, J., Pawlowski, J., 2015. Accurate assessment of the impact of salmon farming on benthic sediment enrichment using foraminiferal metabarcoding. Mar. Pollut. Bull. 100, 370-382. doi:10.1016/j.marpolbul.2015.08.022

$\mathrm{R}$ Core Team, 2015. $\mathrm{R}$ : A language and environment for statistical computing ( $\mathrm{R}$ foundation for statistical computing, Vienna, 2012). URL http// www. R-project. org.

Schafer, C.T., 2000. Monitoring nearshore marine environments using benthic foraminifera $\square$ : Some protocols and pitfalls. Micropaleontology 46, 161-169.

Schafer, C.T., 1973. Distribution of foraminifera near pollution sources in Chaleur Bay. Water. Air. Soil Pollut. 2, 219-233. doi:10.1007/BF00655698

Schafer, C.T., 1971. Sampling and spatial distribution of benthonic foraminifera. Limnol. Oceanogr. 16, 944-951. doi:10.4319/1o.1971.16.6.0944

Schönfeld, J., 2002. A new benthic foraminiferal proxy for near-bottom current velocities in the Gulf of Cadiz, northeastern Atlantic Ocean. Deep. Res. Part I Oceanogr. Res. Pap. 49, 1853 1875. doi:10.1016/S0967-0637(02)00088-2

Schönfeld, J., Alve, E., Geslin, E., Jorissen, F., Korsun, S., Spezzaferri, S., Abramovich, S., Almogi-Labin, A., du Chatelet, E.A., Barras, C., Bergamin, L., Bicchi, E., Bouchet, V., Cearreta, A., Di Bella, L., Dijkstra, N., Disaro, S.T., Ferraro, L., Frontalini, F., Gennari, G., Golikova, E., Haynert, K., Hess, S., Husum, K., Martins, V., McGann, M., Oron, S., Romano, E., Sousa, S.M., Tsujimoto, A., 2012. The FOBIMO (FOraminiferal BIoMOnitoring) initiative-Towards a standardised protocol for soft-bottom benthic foraminiferal monitoring studies. Mar. Micropaleontol. 94-95, 1-13. doi:10.1016/j.marmicro.2012.06.001

Sen Gupta, B.K., 2002. Modern foraminifera. Kluwer Academic Publishers, Dordrecht.

Skilton, J., Tiernan, F., Pannell, N., 2015. Post-Drill Benthic Ecological Assessment at the Oi Well Sites $\square$ : October 2014. Nelson: Resource and Environmental Management Ltd.

Stoeck, T., Zuendorf, A., Breiner, H.W., Behnke, A., 2007. A molecular approach to identify active microbes in environmental eukaryote clone libraries. Microb. Ecol. 53, 328-339. doi:10.1007/s00248-006-9166-1

Taberlet, P., Coissac, E., Hajibabaei, M., Rieseberg, L.H., 2012. Environmental DNA. Mol. Ecol. 21, 1789-1793. doi:10.1111/j.1365-294X.2012.05542.x

Thiel, H., Pfannkuche, O., Schriever, G., Lochte, K., Gooday, A.J., Hemleben, C., Mantoura, R.F.G., Turley, C.M., Patching, J.W., Riemann, F., 1989. Phytodetritus on the deep-sea floor in a central oceanic region of the Northeast Atlantic. Biol. Oceanogr. 6, 203-239.

Valentini, A., Pompanon, F., Taberlet, P., 2009. DNA barcoding for ecologists. Trends Ecol. Evol. 24, 110-117. doi:10.1016/j.tree.2008.09.011 
Vrijenhoek, R.C., 2009. Cryptic species, phenotypic plasticity, and complex life histories:

Assessing deep-sea faunal diversity with molecular markers. Deep. Res. Part II Top. Stud. Oceanogr. 56, 1713-1723. doi:10.1016/j.dsr2.2009.05.016

Walton, W.R., 1952. Techniques for recognition of living foraminifera. Contrib. from Cushman Found. Foraminifer. Res. 3, 56-60.

Wentworth, C.K., 1922. A scale of grade and class terms for clastic sediments. J. Geol. 30, $377-$ 392. doi: $10.1086 / 622910$ 


\section{List of figures}

Figure 1. Site map indicating: A) study site situated in the Taranaki Bight. The green open circle shows location of the Oi operation site; black open circles show locations of north and south controls. B) The Oi operation site with typical arrangement of the sampling stations (full circles) with numbers corresponding to the distance to drilling wells (Oi-1 and Oi-2) along the major water flow axis (modified from Johnston et al., 2014).

Figure 2. Principal coordinate ordination (PCO) analysis of: (A) foraminiferal eRNA, and (B) macrofaunal count data (MCD). $\mathrm{Ctl}=$ control; numbers above icons correspond to the distance to wellheads in meters.

Figure 3. Shade plot of the 20 most prevalent taxa of the environmental RNA (eRNA) dataset over a spatial gradient from wellheads. Number of eRNA reads were standardized per sample and fourth root transformed. Species with a Pearson correlation $>|0.35|$ with distance from wellheads are in bold.

Figure 4. Principal Coordinate Ordination (PCO) analysis of environmental variables among investigated stations (replicates averaged per station). Selected Operational Taxonomic Units (OTUs) and physico-chemical variables (Pearson correlations $>|0.55|$ ) are overlaid to show the trends with individual stations. OTUs with decreasing relative read abundance with distance from wellheads are in bold while those with increasing relative read abundance are not. The color pie charts represent the relative prevalence of each of eight foraminiferal OTUs along the PCO gradient (see legend).

\section{List of tables}

Table 1. Diversity and taxonomic distinctness indices along a spatial gradient from wellheads for the environmental RNA (eRNA), environmental DNA (eDNA) and macrofaunal count data (MCD) datasets. Pseudo-F, P and $\mathrm{R}^{2}$ values from DistLM tests using fourth root transformed distance from wellheads are provided below. Significant values are shown in bold. 


\section{Figure1}

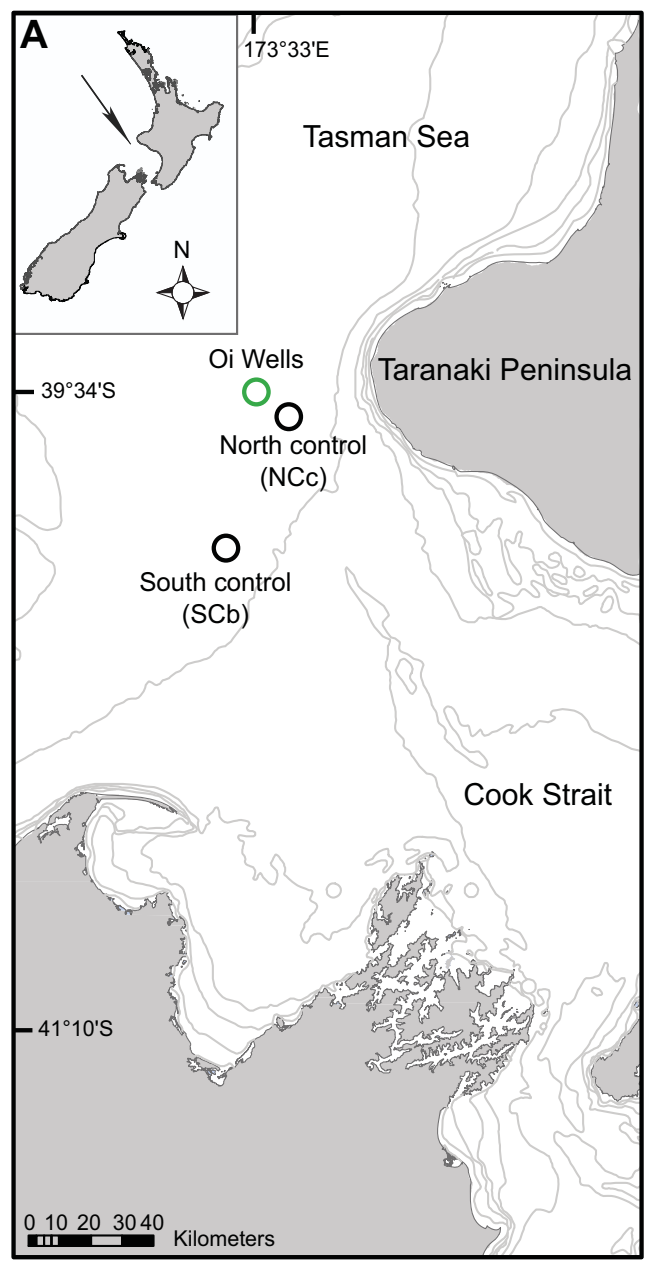

B

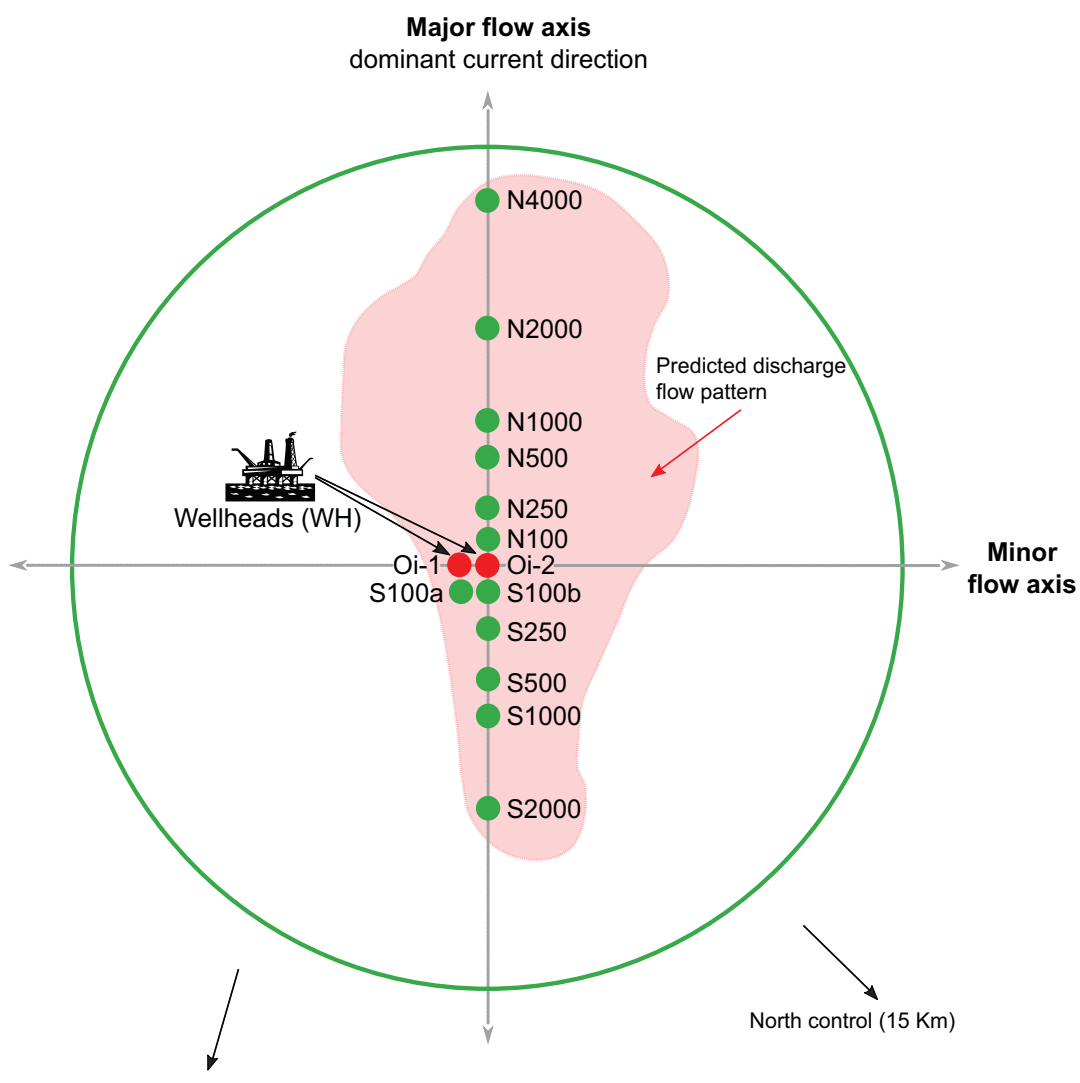

South control $(50 \mathrm{Km})$ 
Figure 2
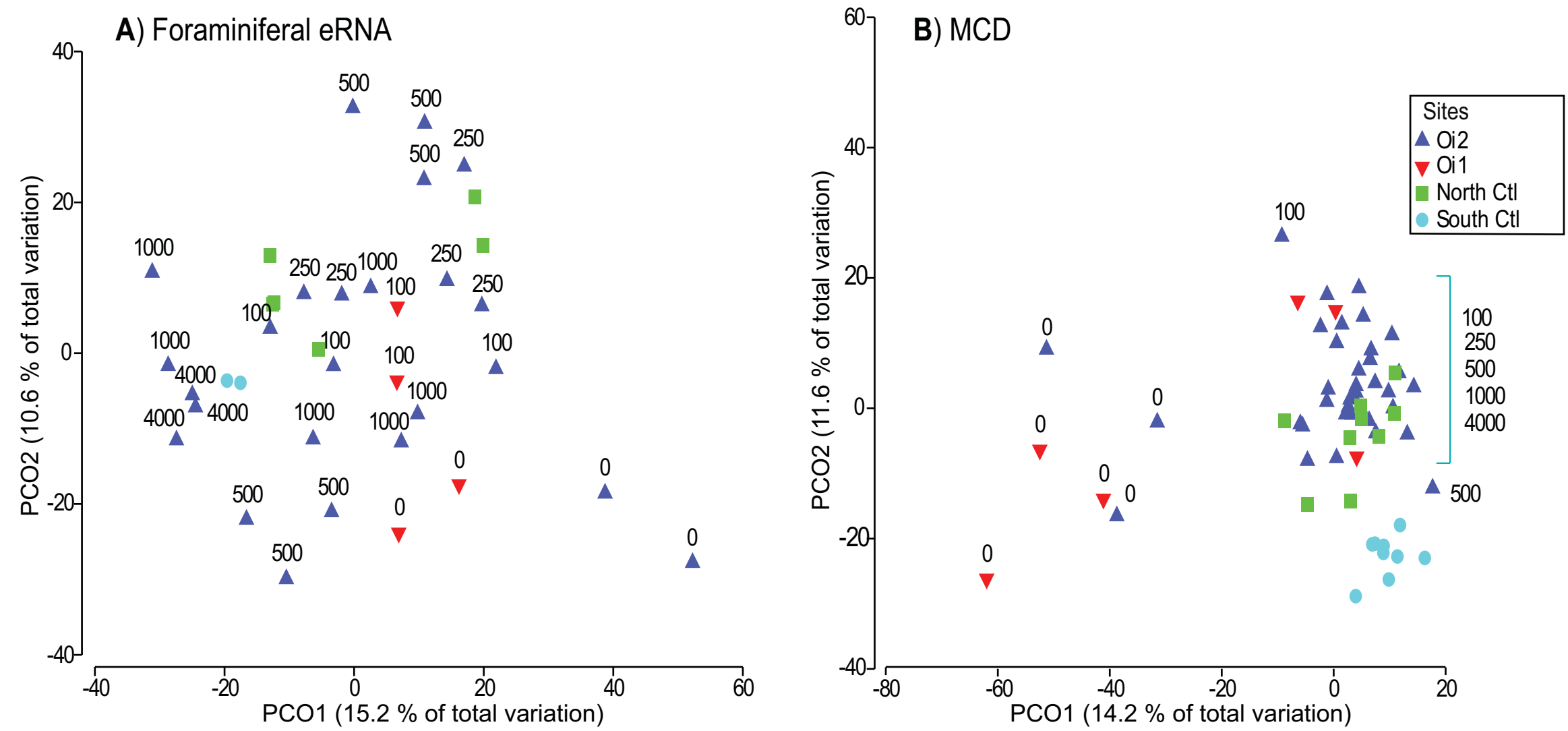


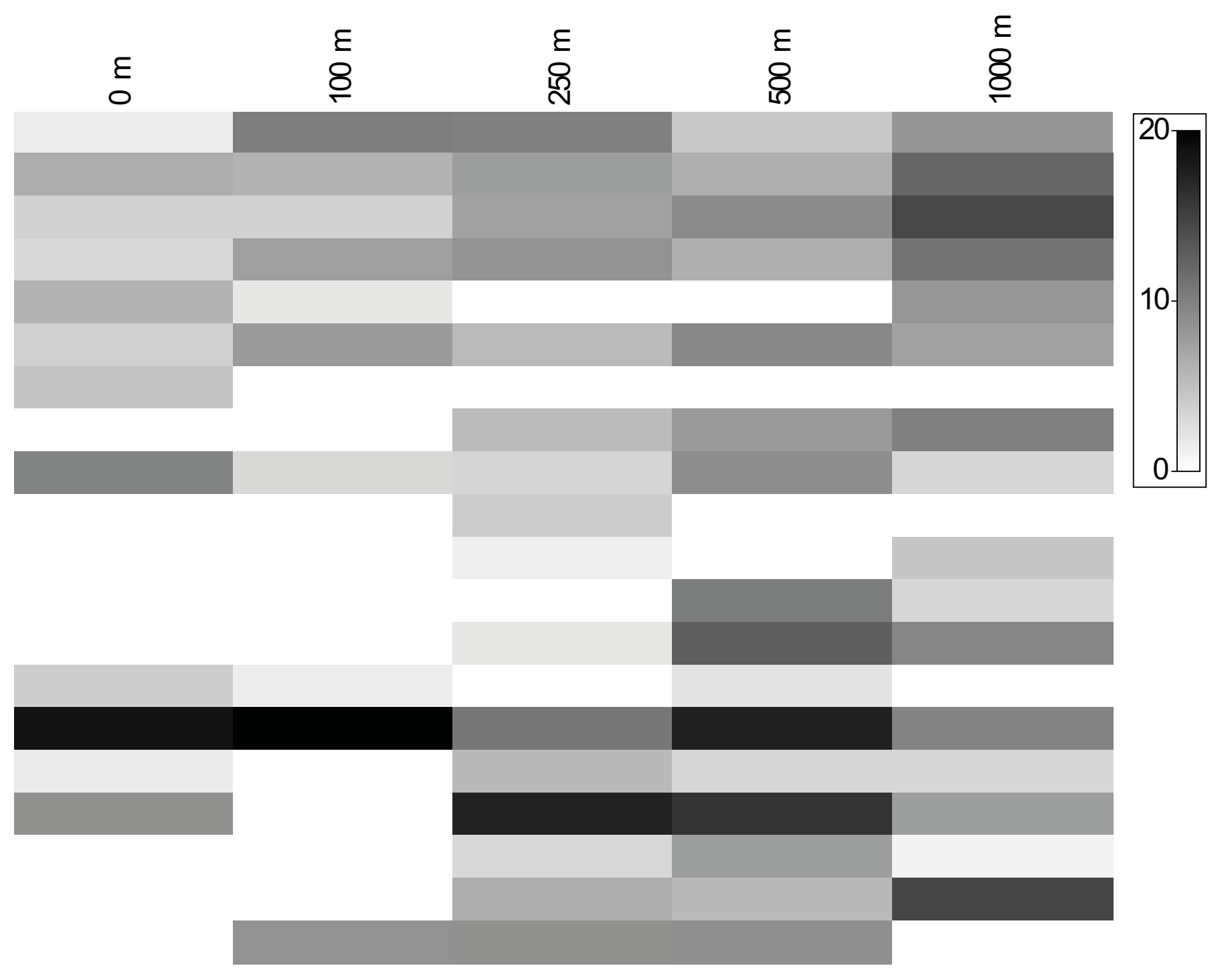

Nonion sp. (OTU 115)

Monothalamid Clade (OTU 144)

Monothalamid Clade (OTU 145)

Globothalamid Clade (OTU 208)

Globothalamid Clade (OTU 21)

Globothalamid Clade (OTU 217)

Globothalamid Clade (OTU 226)

Reophax sp. (OTU 23)

Globothalamid Clade (OTU 234)

Globothalamid Clade (OTU 235)

Globothalamid Clade (OTU 239)

Monothalamid Clade BM (OTU 265)

Monothalamid Clade (OTU 297)

Monothalamid Clade (OTU 313)

Bathysiphon sp.1 (OTU 32)

Monothalamid Clade (OTU 339)

Bathysiphon sp.2 (OTU 34)

Unidentified (OTU 371)

Monothalamid Clade ENFOR9 (OTU73)

Nemogullmia sp. (OTU 95) 


\begin{tabular}{|l} 
A. Monothalamid Clade \\
(OTU 145) \\
B. Reophax sp. \\
(OTU 23) \\
C. Monothalamid Clade \\
(OTU 297) \\
D. Monothalamid Clade \\
(OTU 73) \\
E. Globothalamid Clade \\
(OTU 226) \\
F. Globothalamid Clade \\
(OTU 234) \\
G. Monothalamid Clade \\
(OTU 313) \\
H. Bathysiphon sp.1 \\
(OTU 32)
\end{tabular}

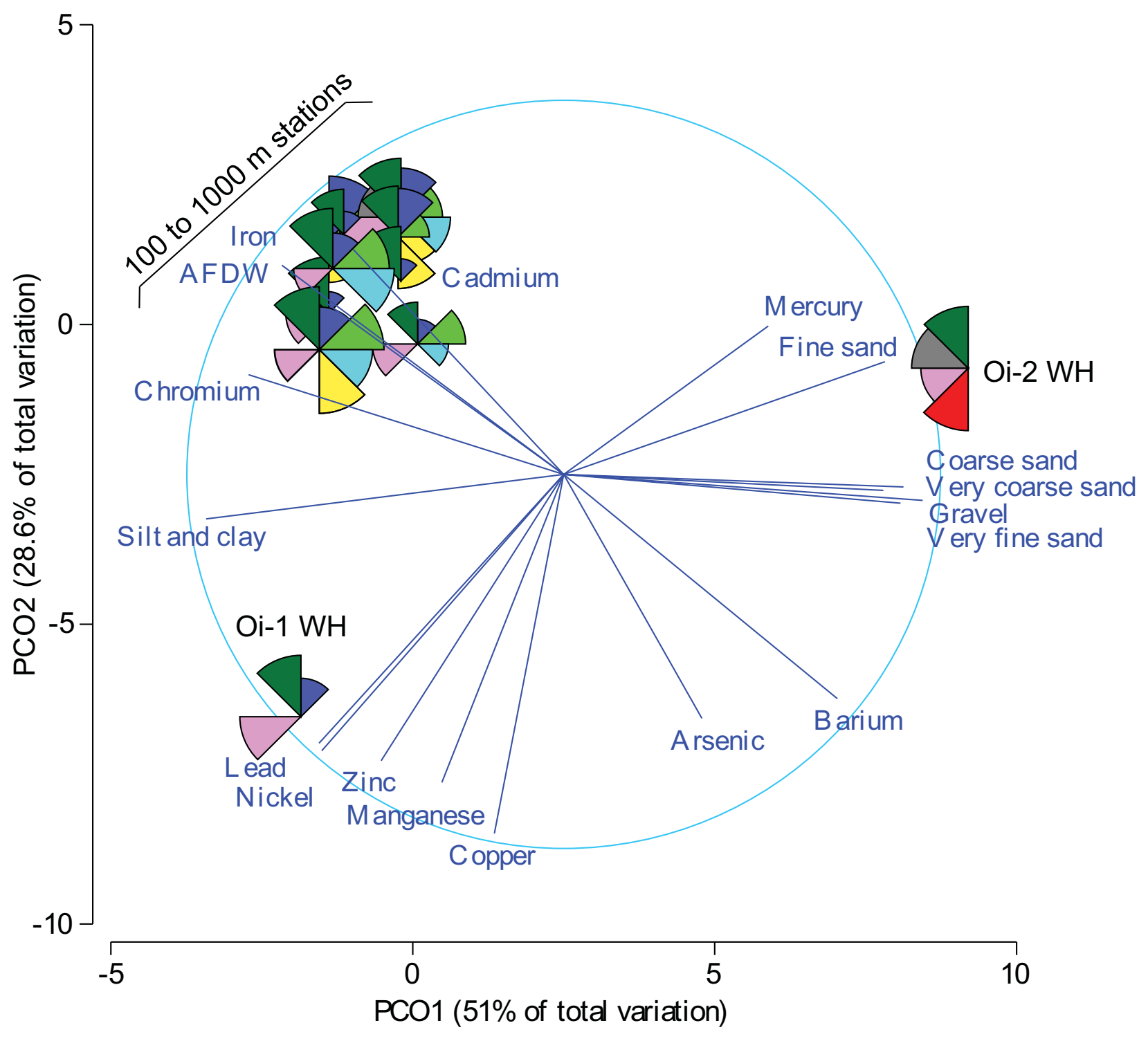


Table 1. Diversity and taxonomic distinctness indices along a spatial gradient from wellheads for the environmental RNA (eRNA), environmental DNA (eDNA) and macrofaunal count data (MCD) datasets. Pseudo-F, $\mathrm{P}$ and $\mathrm{R}^{2}$ values from DistLM tests using fourth root transformed distance from wellheads are provided below. Significant values are shown in bold.

\begin{tabular}{|c|c|c|c|c|c|c|c|c|c|c|c|c|c|c|}
\hline \multirow[b]{2}{*}{ Dist. } & \multicolumn{3}{|c|}{$\begin{array}{l}\text { No. of OTUs } \\
\text { /species }\end{array}$} & \multicolumn{3}{|c|}{$\begin{array}{c}\text { Margalef diversity } \\
\text { index }\end{array}$} & \multicolumn{2}{|c|}{$\begin{array}{l}\text { No. of 'reads' } \\
\text { /specimens }\end{array}$} & \multicolumn{3}{|c|}{$A v T D$} & \multicolumn{3}{|c|}{ VarTD } \\
\hline & eRNA & eDNA & $\mathrm{MCD}$ & eRNA & eDNA & $\mathrm{MCD}$ & eRNA eDNA & MCD & eRNA & eDNA & $\mathrm{MCD}$ & eRNA & eDNA & $\mathrm{MCD}$ \\
\hline 0 & 17 & 13 & 10 & 5.3 & 3.98 & 3.68 & 1475714465 & 29 & 70 & 56 & 92 & 1004 & 686 & 242 \\
\hline 100 & 23 & 19 & 21 & 6.6 & 5.56 & 6.46 & $\begin{array}{ll}6680 & 8017\end{array}$ & 44 & 70 & 70 & 91 & 973 & 1000 & 265 \\
\hline 250 & 17 & 15 & 22 & 5.28 & 4.73 & 6.74 & 538411038 & 49 & 72 & 70 & 94 & 940 & 1015 & 194 \\
\hline 500 & 25 & 19 & 26 & 7.04 & 5.52 & 7.63 & 59627283 & 68 & 66 & 68 & 90 & 1055 & 1014 & 285 \\
\hline 1000 & 23 & 17 & 22 & 6.82 & 5.41 & 6.66 & $7490 \quad 16146$ & 51 & 69 & 67 & 92 & 986 & 941 & 242 \\
\hline 4000 & 42 & 29 & 19 & 11.02 & 7.98 & 6.11 & 1663417746 & 42 & 63 & 64 & 92 & 1046 & 1040 & 268 \\
\hline Pseudo-F & 11.97 & 7.3 & 12.39 & 10.31 & 7.26 & 12.34 & & & 3.52 & 1.45 & 0.08 & 0.47 & 6.03 & 0.23 \\
\hline$P$ & \begin{tabular}{|l|}
0.02 \\
\end{tabular} & 0.01 & $<0.01$ & 0.04 & 0.01 & $<0.01$ & & & \begin{tabular}{|l|l}
0.08 \\
\end{tabular} & 0.24 & 0.78 & 0.50 & 0.02 & 0.64 \\
\hline$R^{2}$ & \begin{tabular}{|l}
0.31 \\
\end{tabular} & 0.21 & 0.27 & 0.28 & 0.21 & 0.27 & & & 0.12 & 0.05 & $<0.01$ & 0.02 & 0.18 & 0.01 \\
\hline
\end{tabular}

